\title{
Constitutional exceptions of right to speech: Evidence from the decisions of apex courts of Pakistan
}

\author{
Kashif Javed* | Li Jianxin | Asif Khan \\ School of Law, Zhengzhou University, Zhengzhou, Henan, China. \\ *Correspondence Emails: kashif.javed@gs.zzu.edu.cn
}

Published: August 25, 2021

\begin{abstract}
Every right is subject to some correlated duty. The Constitution of Pakistan has envisaged certain limitations on the ultimate right to speech. Unqualified fundamental rights ought not to exist in a society. Freedom of speech is known as a pre-condition to all sorts of fundamental rights yet has certain limitations regarding its enjoyment. The restriction on the basic right to speech under the Constitution can be stated as the problem statement of this research. While unveiling the restrictions provided in the Constitution of Pakistan is the basic research question and the research objective is to find out the adequacy of restrictions regarding freedom of speech and draw an inference in the light of case laws. The following article's qualitative research comprises a case law study that elaborates judicial precedents regarding limitations on freedom of speech. This research article emphasizes that the right of freedom of speech must prevail in all the circumstances, yet the citizens are also accountable and have to face the music otherwise. On the other hand, the court must remain impartial while interpreting the Constitution with the prudent mind in a broader spectrum. The theory of necessity must be buried under the deep layers of earth.
\end{abstract}

Keywords: constitution, unqualified right, limitations, apex court, superior court, judicial precedents, pre-condition.

\section{How to Cite:}

Javed, K., Jianxin, L., \& Khan, A. (2021). Constitutional exceptions of right to speech: Evidence from the decisions of apex courts of Pakistan. Journal of Humanities, Social and Management Sciences (JHSMS), 2(1), 72-84. https://doi.org/10.47264/idea.jhsms/2.1.7

\section{Publisher's Note:}

IDEA PUBLISHERS (IDEA Journals Group) stands neutral regarding jurisdictional claims in the published maps and institutional affiliations.

\section{Copyright:}

(C) 2021 The Author(s), published by IDEA PUBLISHERS (IDEA Journals Group)

This is an Open Access article published under the Creative Commons Attribution-Non Commercial 4.0 International License (http://creativecommons.org/licenses/by-nc/4.0/) 


\section{Introduction}

It is admitted that the right to speech is a right by birth and always prevails as a key factor in a democratic society. In spite of this, it took a long time to be admitted by the supreme authorities of the countries round the world to take its right place. However, suppose the basic existence of a state has become a question mark due to misuse of freedom of speech by miscreants or non-state actors. In that case, the fundamental rights may also be restricted in the greater interest of the nation. In the modern age of rights and duties, the concept in the sense of absolute, unrestricted, or unbridled rights does not prevail. There are many motives for which a democratic state can restrict the rights of citizens. The dignity of the court or an individual is a protected right. Hence, in all these circumstances, the phenomenon of restrictions in the public interest at large may escalate. This idea of imposing limitations has been evolved for "protecting each other".

The Constitution of the Islamic Republic of Pakistan reveals that freedom of speech is a fundamental right of the people living within the jurisdiction of Pakistan. Article 19 of the Constitution deals with the freedom of speech and does carries certain limitations as well. This paper has to discuss with the limitation provided under article 19 of the Constitution of Pakistan, 1973, and whether these are for the fundamental right of speech or against the ambit of the right to speech. To dig out the facts, quantitative studies of the judicial precedent of the apex courts of Pakistan have been carried out. It is evident from the facts that freedom of speech is the most significant right that people avail in sovereign countries. Hence, this right must be guarded most of all. The comprehensive studies unveil the facts that the interpretation of the right and the limitations provided under the Constitution has to be done without the unbiased approach. There must be the prudence of mind and juxta positioning of the items before uttering any order of judgment regarding for or against the availing of the fundamental right to speech.

The interpretation of words or acts that falls under the ambit of defamation requires the prudent mind to decide the matter; otherwise, there would be the possibility of bloodshed. Hence, limitations on certain rights of great importance, sometimes if inserted properly, strengthen the right itself and sometimes, if done conversely, may damage the spirit of right and a society without right cannot exist in this modern era.

\section{Literature review}

The first thing to keep in mind in any kind of reasonable conversation of freedom of expression is that it will undoubtedly need to be restricted. Every culture puts some limitations on freedom of speech because it constantly occurs within a context of contending worth (Van-Mill, 2021). according to Stanley Fish, "free speech, in short, is not an independent value but a political prize" however, it holds true that no culture has actually existed where speech has actually not been restricted somewhat (Fish, 1994). in 1998 Haworth points it out likewise as he safeguards that a right to speech freedom is not like something we have, not like something we hold, similarly as we own up limbs (Haworth, 1998). Speech freedom sums up several tasks: talking, creating, vocal singing, acting, melting flags, screaming on the street edge, advertising and marketing, risks, aspersion, and more. One factor for believing that speech freedom is not a unique simpliciter is that a few of these interactions are more crucial than others as well as thus need various degrees of fortification (Alexander \& Horton, 1984). The speech must be shielded since it results in the fact; there appears no factor to protect the speech of anti-inoculations or 
Constitutional exceptions of right to speech: Evidence from the decisions of apex courts

doctrines (Mill, 1978). He recommended that making use of civil liberty can fairly be restricted if it triggered injury to other people (Mill, 1859). Feinberg (1988) 's crime concept clarifies that identifying the infraction can be extremely deeply really felt which its issues are perhaps greatly damaging (Feinberg, 1988). Brandet has indicated that "it is difficult to draw a line between speech that might be regulated and speech that should be tolerated in any liberal society. In contrast, the difficulty is always harmonizing the corresponding rights or purposes" (Barendt, 1994).

\section{Research methodology}

Checking out the parameters for the research aims, the research study included or prepared for research focal point on a selection of resources. Provided the set aim, this study design was embraced to have better accuracy and also deepness evaluations of the research study, readily accessible secondary data was used thoroughly. The researcher acquires the required data via secondary study methods, different newspaper research articles, and the website used, which were itemized and videotaped. Various journals, publications, reports, posts, treaties, public files, customized, legal mottos, and enactments were covered and noted where needed. The study approach will undoubtedly be root in the qualitative methodology. These methodologies will be embraced for study because library-based research study consists of nationwide and worldwide books, Research study articles, worldwide journals, reports, and released short articles. The web databases and wide-ranging publications from websites are the primary resources for collection data.

\section{Judicial precedents from the apex courts of Pakistan}

The Apex Court of Pakistan has laid down number of judgments relating the right to speech and the constitutional limitations of right to speech. In a reported judgment of the Supreme Court of Pakistan, it was held that the constitutional right to speech is not absolute or unbridled. This right may be limited if reasonable grounds are available to curtail the right of speech. The Supreme Court of Pakistan declared that there would be no negotiations regarding the rights postulated in the Constitution of Pakistan. These rights are subject to a number of obligations and responsibilities that must necessarily be adhered to (Masroor Ahsan versus Ardeshir Cowasji, 1998). Court further elaborated that the ironic or cynical expression, the uninterrupted speech, the absurd and embarrassing publications should be avoided with the intention of ironic blackmail. Exploitative journalism is condemnable due to its mal effects and social discomfort. The same was acknowledged as it was held that despite free speech as a constitutional right, Press is not free to publish any material without prior verification and not allowed to violate the established social norms of morality (Miss Sadia Sumble Butt versus Rafiq Afghan, 2006).

Press enjoys a wide range of freedom of speech. Due to its pivotal role, it has become the fourth pillar of the State. No one can deny important speech, especially electronic, print, and social media. On the other hand, the State also must make sure that the rights of others would not be curtailed during the process of awarding freedom of speech. Court more maintained that the speech freedom was never proposed to establish an out-and-out license to speak and to publish anything that pleases a single one. It does not mean that freedom from all legal liability is false thereof (Muhammad Safdar versus West Pakistan, 1965). Again, it was again cited that the right to speech and liberty is not an unconditional and unqualified right for all the times and 
circumstances (Nawab Zada Nasrullah Khan versus Government of West Pakistan, 1965). However, it does not mean that people are bound to distribute printed materials under provided circumstances; just they have to avoid sensationalism.

Freedom of expression surely will not permit to mar the privilege and esteem of citizens or individuals of this nation state (State versus Pakistan Medical and Dental Council of Islamabad, 1989). In another reported case, it was held that Fundamental Rights cannot be interpreted or interpreted in an unexpected or twisted way. Still, when interpreting the constitutional rights guaranteed by the Constitution, you must always bear in mind the principle that these securities are subject to the following requirements: exchange or public interest (Pakistan Muslim League (N) through Khawaja Muhammad Asif, M.N.A. versus Federation of Pakistan, 2007). Thus "the court must consider whether the restriction is reasonable and within the sphere of need and is at such a minimum condition which is necessary to maintain the basic criteria".

\subsection{The principal to limit the constitutional right}

Whenever a constitution shields some rights, and there is a law for its regulation, then every attempt to limit or curtail these rights would qualify the Reasonableness test and necessity of overriding public interest at large. In the case of court held very cunningly, there can be no absolute test of realistic restraints on the right to speech. It will be the court to decide what sort of restriction is reasonable and which one is not rational (Taffazal Hossain versus Government of East Pakistan, 1969). Court identified that if a communication is made in the sense of putting any allegation or personally defaming without proper reason and it is not going to create any anarchy, chaos, or hazard to safety will not amount to subvert the law.

Inevitable limited restraints regarding free Press in the interest of a nation on special circumstances may be justified, but it will not be treated as a general rule; it will be termed only as an exception and a quite special condition to the general rule (Aligarh Muslim University Old Boys Cooperative Housing Society Limited versus Muhammad Yousef Qureshi, 1997). It might be allowed to curtail the freedom only in severe crises where there the prime motive is to uphold the security and integrity of a nation. Although the scope of Article 19 has been widened, it does not give the permit to journalism to release such product, which is biased to the passion of anybody or might create or damage damages to the track record, honor, as well as status of an individual. The desired publication is not allowed by press (Sheikh Muhammad Rashid versus Majid Nizami, 2002).

\subsection{The test of reasonableness of limitation}

When we discuss the "test for reasonableness of restriction", we must address all the related Issus. The first thing to be considered is "Balance". Both the right of the speaker and listener should be protected simultaneously. Secondly, it is also important for the court to determine the spirit of the restriction and the method adopted for this restriction to be followed. Thirdly the restrictions must be in an objective manner. This core concept of impartiality demands that the judges abstain from indulging their own objectives and personal priorities in determining the limitations. They must always decide all the cases with a prudent mind and in a broad spectrum. The United States Constitution, which is reflected as an extremely open-minded document, in its first modification disallowed the Congress from legislating against free Speech 
Constitutional exceptions of right to speech: Evidence from the decisions of apex courts

or Press yet has some restrictions depending upon the protection of other fundamental rights of a citizen.

\subsection{The bounded right to speech under the constitution of Pakistan}

Restrictions on free speech that reads in original text have clearly drawn a line between the right and its boundaries (Constitution of Pakistan 1973, article 19). Court has interpreted this boundary in different cases by delivering speaking orders. Freedom envisaged in fundamental rights is not unquestionable but subject matter to equitable constraints (Rases Ghulam Sarwar vs Mansoor Sadiq Zaidi, 2008). Similarly, it has been declared that the right envisaged in article 19 is not an absolute right (Engr. Jameel Ahmed Malik versus Pakistan Ordinance Factories Board, Wah Cantt, 2004). Hence, rational restraints on reasonable grounds might be imposed depending upon the facts of the case. An unqualified and unobstructed privilege has no reason to exist in this century (D.G. Khan Cement Ltd versus Federation of Pakistan, 2013).

Liberty beyond the borders and with the check on it cannot work in this era of rights with certain duties. The communal benefits of masses at large with mutual harmony and social security are of utmost importance and would never be compromised based on free speech. The sustaining society would be providing the circumstances of availability and enjoyments of fundamental rights for the masses living thereby. This evenness is the basic requirement of a state. Similarly, the voice was raised to benefit Article 19, yet the culprit was punished for not obliging the Government Employees Conduct Rules, 1964 (Amir Hamza, Ex S.S.P versus Federation of Pakistan, 1997).

\subsection{In the interest of honor, safety, protection of state or its any part}

The security, integrity or the Defense of our country becomes a question mark; certain restrictions can be implemented in the greater interest of the State. It is an admitted fact that "united we stand, divided we fall". Solidarity is the foundation of a nation; upholding territorial integrity and national sovereignty is undoubted of great importance for the very existence of a state where the citizens can enjoy their rights. After the integrity, there comes security of the State which may well be threatened by the crimes of violence anticipated to overthrow the Government, waging of war and revolt against the Government, external aggression or war, serious public disorder can also endanger the existence of State or a sign of emergency, in all these situations as the action of defending from or resisting the attack of above said elements, it will be appropriate for the Parliament under this clause to limit the right of freedom of speech by putting some reasonable restriction.

The Pinnacle Court likewise held that every square inch of the region of the state-run being better than the freedom of speech and also expression took pleasure in by any one of its residents, such freedom can out any kind of social, ethical, lawful, or political ground be made use of autonomous ways of selling off the state that has actually presented the freedom. The court also held that the restraints enacted under section 123-A of the Pakistan Penal Code are for the sake of the nation's safety and are more than reasonable. Still, it is allowable for a native to hold up the man who is charged or charged with the executive Government of our country for any wrongdoing or culpable matter (Hussain Bakhsh Kausar versus the State, 1958). 
Fundamental Rights would not be possible to avail if the very existence of the State is at stake. The existence of the State is actually the existence of rights of the public. Simultaneously, if people would not be availing their fundamental rights might not be able to participate in the progress of a country so both are directly proportional. There are also certain exceptions to the general rule. If some group of people is mistaken or even standing on the right footing but have adopted a wrong way, which has threatened the existence of a state, those might not enjoy the fundamental rights for their proper footing. Equilibrium would help in this situation to preserve the challenging benefits. In such a case, the rights of individuals and masses must be dealt with for the collective good of the nation. "Extremist hate literature, wall chalking and threatening, and spiteful press releases were not permissible because they were contrary to the injunctions (of Islam), undermined the integrity, security and Defense of Pakistan, public order, decency and morality, Same were also crimes under the laws of Pakistan, and they incited others to commit the crime. Fear could not be accepted to justify propagating the views of banned organizations" (High Court Bar Association versus Government of Baluchistan, 2013).

\subsection{Relationships regarding the Alien states}

The justification of such restrictions is very clear as if unrestrained malicious propaganda against a friendly foreign state is authorized, it may jeopardize the preservation of good relations between Pakistan and that State. In this era of the joint venture, as the world has become a "Global Village", a state involving mutual dealing between people or parties or countries cannot afford any propaganda against its friendly relations with other states. After World War II, the so-called peace on this earth is due to the harmony and will of co-existence of countries. Some nations are still against his formula. Hence they are not only suffering but also becoming the cause to suffer the other countries. Pakistan is fighting a war on terror as an essential alloy of United Nations and a vibrant Islamic countries member. In these utmost circumstances, killing Chinese engineers in Baluchistan, killing cliff hangers in Gilgit Baltistan, waging war, and planning to attack any other country and Ferrari camps destabilizes the security and law and order in Pakistan and also threatening the friendly relations with other states. The protection of Pakistan act authorizes the imposition of restrictions on the movement to persons who act or are about to act in style injurious to the peripheral affairs of Pakistan.

\subsection{Constraint on the basis of public peacefulness}

"Public order is a condition characterized by the absence of widespread criminal and political violence, such as kidnapping, murder, riots, arson, and intimidation against targeted groups or individuals". Public order has wide meanings in itself, but the basic theme is the condition of calmness in society as considered to be a state of public order. This is because of the rules and regulations made and executed by the country. It is more than just law and order; I require the ceasefire, peace, harmony, and a sense of security in society. If we want to measure the effect of promulgation of the law, whether it helps or disturbs society's living. Anything that disturbs public calmness or public harmony disrupts public order. Thus, common disorders and strikes encouraged with the sole object of initiating unrest among peoples are violations against public order. Public order thus denotes a lack of violence and an organized state of affairs in which people can quietly chase their normal routines of life.

Court also held in Taffazal Hussain versus Government of East Pakistan that the various Public Safety Acts, to the extent of their object, maintain public order are reasonable restrictions on 
Constitutional exceptions of right to speech: Evidence from the decisions of apex courts

the freeness of speech, and the identical standard will put on to orders under Security of Pakistan Act, 1952. It was also held that an order u/s 144 and u/s 107, Criminal Procedural Code, barring communications probable to interrupt the community mandates, is sheltered. Pakistan Penal Code has also postulated certain provisions regarding unlawful assemblies, riots and abetments of offences. As we know, that exception is always there. Some processions which do not amount to the public disorder may be allowed (K.A Muhammad Khan versus The State, 1964).

In an Suo Moto case no 7 of 2017, The Supreme Court of Pakistan passed the judgment that freedom of speech and assembly in the shape of protest can not be exercised by contravening the fundamental legal rights of humans, and also without getting previous authorization the public assembly can not be held on roadways neither can a roadway be utilized as an outdoor camping ground or to put together on it forever as roadways are for lorries and also the sidewalks are for the pedestrians to make it possible for the taking a trip public to relocate openly as in the exercise of a fundamental right (Suo Moto case no 7 of 2017, 2019).

\subsection{In the concern of decency or morality}

Decency basically means lack of obscenity. The right of free speech does not extend to indecent or immoral utterances and publications. In English, common law obscenity was used to express this term, but it is used in the Constitution of Pakistan in the wider sense. The word obscene in these provisions has been held to mean anything uttering or proposing notions sinful, immodest, polluted, lewd and vulgar or calculate to increase the appetites. Human beings are always in search for some new discoveries. Because, still, the universe is explore able. It is an admitted fact that whenever humanity is swiped out from this universe in the shape of floods, earth quacks or similar causes, the main thing was that humanity lost its norms of morality. Free sex is never productive; pornography has destroyed the basic norms of society. We cannot afford the trade or spreading of obscene words, etc., especially in public places. Unfortunately, we could not decide yet what comes under decency and what under obscenity. We have our own standards to judge this rule.

The decorum in routine matters, respect in verdicts, purity, gentility, and moral character in sexual matters are the basic requirements of humanity. It is the reason for which Pakistan has blocked to excess websites and their possible links carrying porn material in Pakistan. YouTube is also banned due to carrying porn and blasphemous material. Although it has created loss on economic ends, but nothing is above than character of a nation. When we come to study the laws relating to pre-censorship, it becomes crystal clear that the State wants to fulfill its duty by promulgating the laws which are limiting the freedom of speech to ensure calm in society at the earliest stage. Nobody should be allowed to publish a book or make a film or documentary if it causes the blasphemy, defamation, or immoral activity. We cannot spare rights without duties because we the humans have struggled for thousands of years to understand and establish this important concept.

\subsection{Restrictions on the bases of contempt of court}

Mr. Justice Arthur T. Vanderbilt has appropriately quoted about the importance of courts. In the honest populations, courts are always empowered to punish the people who commit 
Contempt of the Court as if the court is not dignified, the decisions would be glorified. It was also a landmark case in the history of Pakistan when a sitting Prime Minister was punished due to Contempt of Court for not writing a letter as the supreme Court ordered to report to Swiss bank regarding some accounts. The prime minister was kept standing for around 30 seconds as punishment. However, this was a symbolic or token punishment but Prime Minister resigned from his designation. In a reported case, Sindh High Court observed that if by any action of gesture or words written or spoken the court is scandalized, or a court of law or a sitting judge therein brought into disgust, mockery or any else kind of contempt, such person would be guilty of Contempt of Court. However, Article 204 cannot be interpreted in isolation without taking it into consideration. The Islamabad Court also declared that the constitutional right to free speech is limited. Certain restrictions regarding courts' honor are necessarily observed while enjoying this exclusive right (Baz Muhammad Kakar versus State of Pakistan, 2012).

The arguments or comments regarding the case must be within the limit of free speech. The honor and dignity of the court have to be observed at each and every cost. Any such violation of court may lead to loosen the confidence of court as well as the peoples and resultantly all the orders and judgments will become mere papers and no one will adhere to it if once it loses its sanctity. This will be great harm to society. Administration of justice will only be possible if the honorable court would be delivering their verdict with honor and prestige. In case of any malpractice contrary to the norms beings adopted in court may lead to Contempt of Court and the contempt proceedings against such person may be initiated therein. In the reported case of, contempt of court proceedings were initiated against the alleged contemnor for bringing judges into hatred, ridicule and for contempt for using the scandalous word "shameful" to describe the judiciary; which prima facie, tantamount to ridiculing and abusing the judiciary (Imran Khan, Chairman of Pakistan Tehrek.i.Insaf, 2014). The Supreme Court noted that "legislators and other public figures that have a vision and observe society should use a more decent and protected language and should be more cautious when picking words at public assemblies or press sessions to show brainpower, mental mellowness and insight. It is respect for various national institutions and presenting itself as a role model for society in general".

Publication of a fair and substantially accurate report of any judicial proceedings, including any comments on merits of a pending case, is subject to a prohibition under S. 9, Contempt of Court Act, 1976 or under any other applicable law. Editor, Printer, and Publisher enjoy no special privilege in the matter of publication of briefs, pleadings, or petitions even without comments if such publication is one-sided and may well have the undesirable effect of prejudicing the party whose version is not placed before the public, the same would be punishable for Contempt (Masroor Ahsan versus Ardeshir Cowasjee, 1998). It was held that the right to free speech does not encompass providing permission to the people to dedicate the Ridicule of Court. In this relation, Art 19 remains in a method about art 204, which currently orders the regulation of Ridicule of the superior Courts. It includes constitutional guard versus any effort to horrify the court or weaken its self-respect in the general public interest rate (The State versus Sheikh Shukat Ali Advocate, 1976).

In a reported judgment, the Supreme Court of Pakistan held that the basic reason for these proceedings is to rehabilitate the dignity and honor of the court. Even the actions of judges in court can be criticized, as long as the criticism is made in good faith. It was observed by an Ombudsman in a case; 'without question' just as the judiciary is important to democracy, so is the freedom of the Press. Indeed, both these institutions have an indispensable role to play in 
Constitutional exceptions of right to speech: Evidence from the decisions of apex courts

evolving a healthy democratic set-up in a country. Therefore no one can have any cavil with the proposition that should the Press come out with 'fair criticism', then it is protected. But if improper motives are attributed to a judge or a court, then a 'fair criticism' is no matter how ingeniously worded will fail to qualify as such and will not protect a contemnor from punishment. In Taj Din and others versus The State, 1975, arming The State versus Taj Din and others, 1972 taking out of a procession with contemptuous placards against a Judge of this Court was held to be the grossest contempt. Freedom of Speech and expression is limited by the rule that no person will be permitted by speech or writing to impede or interfere with the orderly administration of justice. It is just such articulations or works planned to limit the procedure or prevent the management of justice and due regulation process. The legislation associated with the Ridicule of Court and also its demand is totally acknowledged in the nations exercising the Anglo-American System of management of justice.

The apex court deciding a case regarding a talk show, namely "Power Play" on a sub-judice mater, declared that the often-used term of "media trial" is a real sensation and cannot be allowed. If the fate of public matters is going to be decided, public forums would influence the minds of public, lawyers, investigators, and most of all, the reasons of judges tend to prejudice the sub-judice matter (Suo Moto case no. 28, 2018; 2019).

\subsection{Commission or provocation to any crime}

Incitement can be defined as "the action of provoking unlawful behavior or urging someone to behave unlawfully this amounted to an incitement to commit murder; Incitement was an offence under the common law of England and Wales. It was an inchoate offence (Jefferson, 2007).It consisted of persuading, encouraging, instigating, pressuring, or threatening so as to cause another to commit a crime". In statute while defining incitement Section 2A (1) reads incitement as the; "command, request, propose, advise, encourage, or authorize." In (Young versus Cassels, 1914), it was said that: "The word 'incite' means "to rouse; to stimulate; to urge or spur on; to stir up; to animate". Lord Denning in Race Relations Board v Appl he said that "Essentially, the common law definition of incitement aligns quite neatly with the general dictionary definition, however, we should probably add that incitement can also include a person who incites another to do an act by threatening or by pressure, as well as by persuasion" as stated. When we come to offence, we can see that, as "any act or omission made punishable by any law for the time being in force and slightly differently by section 40 of the Pakistan Penal Code" (Mahmood \& Shaukat, 2008).

The legislation of chapter $\mathrm{V}$ in the Pakistan Penal Code, relating to abetment and of section 505 relating to statements conducting to public mischief, is as much as they punish abetment of offences by speech probably fall within this restriction (Munir, 2020). the provision of public safety or preservation of public order is so far as they punish or prevent incitement to offences, and of the "West Pakistan Press and Publication Ordinance, 1963", to the extent they restrict freedom of the Press in the interest of public order, will probably not be treated as violation of the constitutional right to free speech and expression. The above-discussed exemptions were postulated by article 19 of the Constitution. Still, whenever the condition arises where reasonable restrictions are fruitful for the public at large, then even positive things in the eye of some people or groups may be restricted like the case of Pakistan Chest Foundation versus the Government of Pakistan, where the advertisement of tobacco was limited. The court 
decided that if tobacco companies' cigarette-related commercials are not shown on television or broadcast on the radio, which could have the potential to encourage people to smoke cigarettes, neither free speech nor the free press are violated.

All of the above-mentioned limitations were envisioned in the Constitution of the Islamic Republic of Pakistan, which made the right to free speech an unqualified right. The Apex court has also uttered a number of rulings regarding the limitations of right to speech but the thing does not stop here. In recent years, courts around the world have consistently ruled that freedom of expression extends to controversial and shocking artistic work. Therefore, it is evident that the limitations are unavoidable on the right to speech due to ultimate changes in the societies with the passage of time. The important thing is the balance between Right and just limitation because a limitation must not curtail the soul of the right.

\section{Laws related with right of freedom of speech in Pakistan}

The laws which deal with the right of freedom of speech in Pakistan include Article 19 of the Constitution, 1973, Article 204 of the Constitution of the Islamic Republic of Pakistan, 1973, Contempt of Courts Ordinance, 2003, Defamation Ordinance, 2002, The Press Council Ordinance, 2002, Motion Pictures Ordinance, 1979, West Pakistan Use of Loudspeakers (Prohibition) Ordinance, 1963, West Pakistan Maintenance of Public Order Ordinance, 1961, West Pakistan Press and Publications Ordinance (XXX of 1963, Censorship of Films Act (XVIII of 1963), Pakistan Electronic Media Regulatory Authority Ordinance (XIII of 2002), 295-A \& 295-C of the Pakistan Penal Code, 1860, Chapter XXI (Defamation) of the Pakistan Penal Code, 1860, Sedition (S. 124-A) of the Pakistan Penal Code, 1860, S. 12, Security of Pakistan Act, 1952, Punjab Prohibition of Expressing Matters on Walls Act, 1999 and Baluchistan Prohibition of Expressing Matters on Walls Ordinance, 2001.

In 2020, on Press Freedom Index still, Pakistan is on position 145 among 180 countries as compared to the list of 2019 as the position of Pakistan was 142 in that list. It speaks vehemently about the laws of Pakistan (Press Freedom Index, 2020). If the rules are not being followed as per the intent of the legislature would become harmful for humans because, in this case, these are consistently mishandled and used for personal means, especially by the governments to fulfill their unlawful means.

\section{Grounds for restrictions on freedom of speech}

The Supreme court of Pakistan has laid down some grounds for restrictions in a case while deciding a matter of Pakistan Broadcasters Association that, It is true that freedom of expression, as a natural fundamental right, could not be suppressed unless it was being exploited and/or was causing danger to, or in it lies the imminent potential of hurting public interest, or directly putting it at stake, and that the anticipated danger should not be remote, conjectural, or far-fetched; rather, it should have proximate and direct nefarious consequences. The ruling also gives the state the authority to impose restrictions based on reasonableness. When the right to free speech tussles with the rights of others or other societal interests, the state may intervene. The government should knock a reasonable balance between the need to protect people's freedom of expression and enact social control (Pakistan Broadcaster Association versus PEMRA, 2016). Likewise, in deciding the censorship lawsuit of the film "MAALIK, " the Supreme Court stated that in order to override a constitutionally protected right 
to free expression, it must not only meet the criteria of "sufficient importance," but also meet the test of reasonableness. As a result of this, the means used must be rationally related to the goal and should not be arbitrarily applied unfairly or irrationally; they must also have effects on rights and freedoms that are proportional to the purpose (Abdullah Malik versus Ministry of information and Broadcasting, 2017).

\section{Conclusion}

The right without duty is harmful for society. The Constitution of Pakistan has envisaged certain limitations on the right to free speech. The Apex court being the guardian of the Constitution, has decided different cases regarding restrictions on freedom of speech. Restraint may be imposed on any right, but "the test of reasonableness" for the restriction is the key point to be dealt with keen observation and due diligence. Every living must avail his rights but subject to the boundaries described by the law and social norms. The Constitution of Pakistan and the superior courts have guaranteed the rights of all the citizens living under their jurisdiction. The precedents set by the Superior Court are the milestone for interpretation of laws and the restriction imposed on rights. Nobody is at liberty to do whatever he wishes. Everyone must enjoy freedom of speech at every cost but not at the cost of defamation, wagging war and disrespect to the court or any other offences. So as for judicial precedents, we can draw a clear inference that court has the power to interpret the thin line between the right and the duty, but this will only be possible when the court would be unbiased, impartial and must not have double standards. The balance between safeguarding Right to Speech and limiting the same requires a significant observation. Hence applying the best judicious approach by judges may be helpful in resolving the complexities rising in communities. Simultaneously, it is somehow moral obligation of jurist and philosophers of ethics to keep discussing the freedom and boundaries of speech, so that at every point of clash they may put forth a balanced approach of right and duty related with freedom of speech for the awareness of public at large.

\section{References}

Alexander, L., \& Horton, P. (1984). The impossibility of a free speech principle. Northwestern Law Review, 78(5), $1319 \mathrm{ff}$.

Aligarh Muslim University Old Boys Cooperative Housing Society Limited versus Muhammad Yousef Qureshi, CLC 732 (Karachi High Court Sindh, 1997). https://www.amu.ac.in/non-teaching/saiyyid-hamid-senior-secondary-schoolboys/mohammad-yousuf

Amir Hamza, Ex S.S.P versus Federation of Pakistan, PLC 732 (C S, 1997).

Abdullah Malik versus Ministry of Information and Broadcasting, PLD 2017 (Lahore 273).

Asma Jilani versus the government of the Punjab and another, PLD 39 (Supreme Court, 1972). http://andyreiter.com/wpcontent/uploads/militaryjustice/pk/Court\%20Cases/Pakistan\%20-\%201972\%20-\% 20Asma\%20Jilani\%20v.\%20Government\%20of\%20Punjab.pdf

Barendt, E. (1994). Free speech in Australia: a comparative perspective. Sydney L. Rev., 16, 149.

Baz Muhammad Kakar versus Federation of Pakistan, PLD 870 (Supreme Court, 2012). https://cite.pakcaselaw.com/pld-supreme-court/2012/870/ 
Crimes Act 1958 (Vic) reprints. (n.d.). https://www.lawlibrary.vic.gov.au/crimes-act-1958vic-reprints

D.G. Khan Cement Ltd versus Federation of Pakistan, PLD 693 (Lahore High Court, 2013). https://cite.pakcaselaw.com/PLD-LAHORE-HIGH-COURT-LAHORE/2013/693/

Engr. Jameel Ahmed Malik versus Pakistan Ordinance Factories Board, Wah Cantt, SCMR 1640 (Supreme Court, 2004). https://cite.pakcaselaw.com/scmr-supremecourt/2004/164/

Fish, S. (1994). There's no such thing as free speech... and it's a good thing too. Oxford University.

Feinberg, J. (1988). Offence to others. Oxford University (Volume 2 of the moral limits of the criminal law).

High Court Bar Association versus Government of Baluchistan, PLD 75 (Baluchistan, 2013). https://bhc.gov.pk/resources/judgments/justice-qazi-faez-isa/reportedjudgments\#lg $=\mathrm{gl}$ judgements $\&$ slide $=0$

Haworth, A. (1998). Free speech. Routledge

Hussain Bakhsh Kausar versus the State, PLD 15 (Peshawar, 1958). https://peshawarhighcourt.gov.pk/PHCCMS/reportedJudgments.php?action=search

Imran Khan, Chairman of Pakistan Tehrek.i.Insaf, PLD 367 (Supreme Court, 2014). https://cite.pakcaselaw.com/PLD-SUPREME-COURT/2014/367/

Jefferson, M. (2007). Criminal law. Pearson Education.

K.A Muhammad Khan versus the State, AIR 104 (Kerala 1964). https://indiankanoon.org/doc/603304/

Mahmood, S., \& Shaukat, N. (2008). The Pakistan Penal Code (section 40). Lahore: Legal Research Centre.

Masroor Ahsan versus Ardeshir Cowasji, PLD 823 (Supreme Court, 1998).

Miss Sadia Sumble Butt versus Rafiq Afghan, MLD 1462 (Karachi High Court, 2006). https://cite.pakcaselaw.com/MLD-KARACHI-HIGH-COURT-SINDH/2006/1462/

Muhammad Din versus The State, 1995 PLD 469 (Karachi High Court, 1995). https://cite.pakcaselaw.com/PLD-KARACHI-HIGH-COURT-SINDH/1995/469/

Muhammad Nawaz Sharif versus President of Pakistan and others, PLD 473 (Supreme Court, 1993). http://nasirlawsite.com/historic/pld473.htm

Muhammad Safdar versus West Pakistan, PLD 236 (Peshawar, 1965).

Mill, J. S. (1978). On Liberty. Hackett Publishing.

Mill, J.S. (1859) On liberty. Harvard Classics edition, 1909. http://www.serendipity.li/jsmill/on_lib.html

Nawab Zada Nasrullah Khan versus Government of West Pakistan, PLD 642 (Lahore, 1965). https://cite.pakcaselaw.com/PLD-LAHORE-HIGH-COURT-LAHORE/1965/642/

Nawabzada Nasrullah Khan versus The District Magistrate, Lahore \& The Government of West Pakistan PLD 642 (W.P) (Lahore, 1965). https://cite.pakcaselaw.com/PLDLAHORE-HIGH-COURT-LAHORE/1965/642/

Pakistan Chest Foundation versus Government of Pakistan, CLC 1379 (1997). https://cite.pakcaselaw.com/CLC-LAHORE-HIGH-COURT-LAHORE/1997/1379/

Pakistan Muslim League (N) through Khawaja Muhammad Asif, M.N.A. versus Federation of Pakistan, PLD 642 (Supreme Court, 2007). https://cite.pakcaselaw.com/pldsupreme-court/2007/642/

Pakistan Broadcaster Association versus Pakistan Electronic Media Regulatory Authority, PLD 2016 (Supreme Court 692) 
PLD 661 (Lahore 1964). https://cite.pakcaselaw.com/PLD-LAHORE-HIGH-COURTLAHORE/1964/661/

Rases Ghulam Sarwar versus Mansoor Sadiq Zaidi, PLD 458 (Karachi 2008). https://cite.pakcaselaw.com/PLD-KARACHI-HIGH-COURT-SINDH/2008/458/

Sheikh Muhammad Rashid versus Majid Nizami, PLD 514 (Supreme Court, 2002). https://cite.pakcaselaw.com/pld-supreme-court/2002/514/

State versus Pakistan Medical and Dental Council of Islamabad, PLD 12 (Lahore, 1989). https://sys.lhc.gov.pk/appjudgments/2017LHC3892.pdf

Sutlej Cotton Mills Ltd. versus Industrial Court, PLD 472 (Supreme Court, 1966). https://cite.pakcaselaw.com/PLD-SUPREME-COURT/1966/472/

Suo Moto case no 28 of 2018, PLD 2019 (Supreme Court 1)

Suo Moto case no 7 of 2017, PLD 2019 (Supreme Court 318)

Taffazal Hossain versus Government of East Pakistan, PLD 589 (Dacca, 1969). https://cite.pakcaselaw.com/PLD-DHAKA-HIGH-COURT/1969/589/

Taffazal Hussain versus Government of East Pakistan, PLD 68 (Dacca, 1965). http://cite.pakcaselaw.com/PCRLJ-DHAKA-HIGH-COURT/1968/734/

Taj Din and others Versus The State, PLD 490 (SC 1975).

The Security of Pakistan Act, 1952 (Act No. XXXV of 1952). http://nasirlawsite.com/laws/sop.htm

The State versus Abdul Ghaffar Khan (Bacha Khan), PLD 142 (Lahore, 1957).

The State versus Sheikh Shukat Ali Advocate, PLD 355 (Lahore, 1976). https://cite.pakcaselaw.com/pld-lahore-high-court-lahore/1976/714/

The State versus Taj Din and others, PLD 434 (Lahore, 1972).

Van-Mill, D. (2021). Freedom of speech. The Stanford Encyclopedia of Philosophy (Spring 2021 Edition), Edward N. Zalta (Ed.), https://plato.stanford.edu/archives/spr2021/entries/freedom-speech/

Young versus Cassells, 33 N.Z.L.R. 852, 16 G.L.R. 391 (1914). 1993 SCMR 2189. http://www.lawreports.nz/young-v-cassells-1914-33-nzlr-852/ 